\title{
Analisis Elemen AIDA Pada Media Sosial Instagram Sebagai Media Promosi Perpustakaan di Dinas Arsip dan Perpustakaan Kabupaten Bandung
}

\author{
Analysis of AIDA Elements on Instagram Social Media as a Library \\ Promotion Media in the Archives and Libraries Office of Bandung Regency
}

\author{
Diva Thea Theodora Ismail \\ Program Studi Ilmu Perpustakaan dan Informasi, Fakultas Ilmu Komunikasi, Universitas \\ Islam Nusantara \\ divatheodora11@gmail.com
}

Received : $31^{\text {th }}$ May 2021; Revised : $10^{\text {th }}$ June 2021; Accepted : $17^{\text {th }}$ June 2021

Available Online : 20 ${ }^{\text {th }}$ June 2021; Published Regularly : 20 June 2021

\begin{abstract}
The development of information and communication technology today is a challenge for libraries. Libraries must be able to balance it so that it continues to be used by its users. As an information provider, the library must continue to be developed and promoted so that the public can find out about existing services and can utilize library facilities effectively and efficiently. Library promotion is one of the important things in library development. With the promotion of the library can increase the interest of the public to come to the library. Many efforts have been made by libraries to promote libraries, one of which is promotion through social media Instagram. The Bandung Regency Archives and Library Service is a Bandung Regency public library that uses Instagram as a promotional medium. The purpose of this study is to analyze the promotions carried out by the Bandung Regency Archives and Library Service on Instagram social media using AIDA elements. This study uses a descriptive qualitative research method with data collection techniques through interviews and observations conducted on January 20, 2021. The informants in this study amounted to 3 people where the informants were followers of the Instagram account of the Bandung Regency Archives and Library @ disarpus_kab.bandung Instagram account which were taken randomly. random sampling. The results of this study revealed that the promotional efforts carried out by the Bandung Regency Archives and Library Service did not meet the AIDA element, namely the Attention element. Where is the lack of selection of layout and graphic design content in the upload of the @disarpus_kab.bandung Instagram account.
\end{abstract}

Keywords: AIDA Elements; Instagram Social Media; Library Promotion; Public Library

\footnotetext{
Abstrak

Perkembangan teknologi informasi dan komunikasi masa kini dijadikan tantangan bagi perpustakaan. Perpustakaan harus dapat mengimbanginya agar terus dimanfaatkan oleh penggunanya. Sebagai penyedia informasi, perpustakaan harus terus dikembangkan dan dipromosikan agar masyarakat dapat mengetahui layanan yang ada dan dapat memanfaatkan fasilitas perpustakaan secara efektif dan efisien. Promosi perpustakaan merupakan salah satu hal penting dalam pengembangan perpustakaan. Dengan adanya promosi perpustakaan dapat meningkatkan minat kunjung masyarakat untuk datang ke perpustakaan. Banyak upaya yang dilakukan oleh perpustakaan untuk mempromosikan perpustakaan, salah satunya promosi melalui media sosial Instagram. Dinas Arsip dan Perpustakaan Kabupaten Bandung merupakan perpustakaan umum Kabupaten Bandung yang memanfaatkan media sosial Instagram sebagai media promosinya. Tujuan dari penelitian ini ialah untuk menganalisis promosi yang dilakukan oleh Dinas Arsip dan Perpustakaan Kabupaten Bandung dalam media sosial Instagram menggunakan elemen AIDA. Penelitian ini menggunakan metode penelitian deskriptif kualitatif dengan teknik pengambilan data melalui wawancara dan observasi yang dilakukan pada
} 
tanggal 20 Januari 2021. Informan dalam penelitian ini berjumlah 3 orang yang mana informan merupakan followers akun Instagram Dinas Arsip dan Perpustakaan Kabupaten Bandung @disarpus_kab.bandung yang diambil secara random sampling. Hasil dari penelitian ini mengungkapkan bahwasanya dalam upaya promosi yang dilakukan Dinas Arsip dan Perpustakaan Kabupaten Bandung kurang memenuhi elemen AIDA yakni elemen Attention (perhatian). Di mana kurangnya pemilihan konten layout dan desain grafis dalam unggahan akun Instagram @disarpus_kab.bandung.

Kata kunci: Elemen AIDA; Media Sosial Instagram; Promosi Perpustakaan; Perpustakaan Umum

\section{Pendahuluan}

Berkembangnya teknologi informasi dan komunikasi saat ini menjadikan manusia masa kini dituntut untuk mengikuti perkembangannya. Bagi perpustakaan, perkembangan teknologi informasi dan komunikasi masa kini tentunya dijadikan sebuah tantangan. Perpustakaan harus dapat terus mengimbangi perkembangan teknologi informasi dan komunikasi yang ada agar dapat terus dimanfaatkan oleh penggunanya. Perpustakaan memiliki fungsi penting terhadap ketersediaan informasi. Pada dasarnya perpustakaan peranan untuk meningkatkan kecerdasan bangsa melalui ketersediaan koleksi dan layanan yang ada di perpustakaan. Untuk itulah perpustakaan harus dapat terus dikembangkan dan dipromosikan agar masyarakat dapat mengetahui layanan yang ada dan dapat memanfaatkan perpustakaan secara efektif dan efisien. Promosi perpustakaan memiliki peranan yang penting terhadap pengembangan suatu perpustakaan. Melalui promosi perpustakaan dapat meningkatkan minat kunjung masyarakat untuk datang ke perpustakaan. Budiman, dkk (2019) mengungkapkan bahwa promosi perpustakaan adalah suatu wadah yang dapat digunakan untuk menginformasikan, mengenalkan dan memperlihatkan kepada masyarakat tentang apa yang dimiliki perpustakaan baik dari layanan, fasilitas, koleksi serta keunggulan yang dimiliki oleh suatu perpustakaan.

Peranan perkembangan teknologi informasi dan komunikasi dapat dijadikan peluang bagi perpustakaan sebagai media promosi salah satunya dengan promosi perpustakaan melalui media sosial. Van Dijk (2013) mengungkapkan bahwa media sosial merupakan sebuah platform media yang memfokuskan pada eksistensi pengguna yang memfasilitasi mereka dalam beraktivitas maupun berkolaborasi. Saat ini terdapat beranekaragam aplikasi media sosial yang dapat diunduh melalui smartphone yang terkoneksi pada internet, salah satunya ialah Instagram. Instagram merupakan salah satu aplikasi media sosial yang memfasilitasi penggunanya untuk membagikan foto maupun video. Aplikasi Instagram ini dapat diunduh melalui sistem iOS, android, maupun windows phone.

Dinas Arsip dan Perpustakaan Kabupaten Bandung adalah sebuah perpustakaan umum daerah di Kabupaten Bandung. Dinas Arsip dan Perpustakaan Kabupaten Bandung terletak di Komplek Kantor Pemerintah Daerah Kabupaten Bandung pada Jl. Raya Soreang Cincin, Karamatmulya, Kecamatan Soreang, Bandung, Jawa Barat 40912. Layaknya perpustakaan pada umumnya, Dinas Arsip dan Perpustakaan Kabupaten Bandung memiliki beberapa fasilitas layanan bagi penggunanya seperti layanan anak, layanan referensi, layanan umum, layanan digital, Hotspot (Gazebo), pojok sunda, BI Corner, ruang baca umum dan selfi, cafe book, ruang rapat/serbaguna, layanan buku braille, dan perpustakaan keliling. Dengan beragamnya layanan yang tersedia di Dinas Arsip dan Perpustakaan Kabupaten Bandung tentunya dapat memenuhi kebutuhan pengguna. Akan tetapi, pada kenyataannya keberadaan Dinas Arsip dan Perpustakaan Kabupaten Bandung kurang diketahui oleh masyarakat. Berdasarkan hasil observasi sementara yang dilakukan oleh penulis, diketahui bahwasanya masih banyak masyarakat kabupaten bandung yang belum mengetahui sama sekali terkait keberadaan Dinas Arsip dan Perpustakaan Kabupaten Bandung. Bahkan terdapat pula sebagian masyarakat yang baru mengetahui adanya perpustakaan daerah di Kabupaten Bandung.

Dinas Arsip dan Perpustakaan Kabupaten Bandung merupakan salah satu perpustakaan yang memanfaatkan media sosial sebagai media promosi perpustakaan. Dinas Arsip dan Perpustakaan 
Kabupaten Bandung menggunakan aplikasi media sosial Instagram sebagai salah satu media promosi yang digunakannya. Dinas Arsip dan Perpustakaan Kabupaten Bandung memiliki akun resmi dalam Instagram yakni@disarpus_kab.bandung sejak tahun 2017 yang memiliki jumlah pengikut sebanyak 1.246 pengikut dan 237 mengikuti akun Instagram lainnya. Dalam akun @disarpus_kab.bandung terdapat 257 unggahan yang dimuat dalam laman Instagram-nya yang terdiri atas beberapa kegiatan yang ada di perpustakaan. Dalam laman akun Instagramnya Dinas Arsip dan perpustakaan Kabupaten Bandung aktif dalam mempromosikan perpustakaan dengan mengunggah foto maupun video kegiatan-kegiatan yang berkaitan dengan perpustakaan.

Namun dalam upaya promosi perpustakaannya, Dinas Arsip dan Perpustakaan Kabupaten Bandung kurang memperhatikan terkait konten atau unggahan yang diunggahnya melalui akun Instagram @disarpus_kab.bandung tersebut. Di samping itu akun Instagram @disarpus_kab.bandung juga kurang aktif dalam mempromosikan perpustakaan, dapat dilihat jarak pengunggahan foto ataupun video kurang rutin. Tentunya hal tersebut menjadi problema dalam upaya promosi yang dilakukan oleh Dinas Arsip dan Perpustakaan Kabupaten Bandung. Berdasarkan pemaparan latar belakang di atas, maka penulis tertarik untuk mengetahui lebih dalam terkait analisis promosi yang dilakukan oleh Dinas Arsip dan Perpustakaan Kabupaten Bandung melalui media sosial Instagram dengan menggunakan elemen AIDA. Untuk itu penulis melakukan penelitian dengan judul Analisis Elemen AIDA pada Media Sosial Instagram sebagai Media Promosi Perpustakaan di Dinas Arsip dan Perpustakaan Kabupaten Bandung.

\section{Metode Penelitian}

Metode penelitian yang digunakan dalam penelitian ini adalah penelitian deskriptif kualitatif, di mana hasil pembahasan disusun untuk menggambarkan dengan bentuk kata-kata. Basuki (2006) mengungkapkan bahwa metode deskriptif merupakan sebuah kajian yang mendalami mengenai peristiwa, lingkungan, dan situasi tertentu yang memungkinkan untuk mengungkapkan atau memahami suatu hal. Jadi dalam penelitian deskriptif merupakan sebuah kajian yang memuat peristiwa atau situasi yang terjadi. Lexy J. Moleong (2006) menyatakan bahwa penelitian kualitatif merupakan sebuah penelitian yang dimaksudkan untuk memahami fenomena yang dialami oleh subjek penelitian (seperti contohnya perilaku, persepsi, motivasi, tindakan dan lain sebagainya) yang menyajikannya dengan bentuk deskripsi pada suatu struktur khusus yang alamiah dan menggunakan berbagai metode ilmiah. Berdasarkan keterangan dari beberapa ahli di atas, dapat ditarik kesimpulan bahwa penelitian deskriptif kualitatif adalah metode penelitian yang memperoleh data informasi dengan cara mempelajari dan mengumpulkan data berdasarkan keterangan yang sudah ada namun data tersebut tidak seluruhnya dapat diukur dengan angka tetapi lebih menurut pada deskripsi dari hasil ide pendapat persepsi dan kepercayaan objek yang akan diteliti.

Penelitian ini dilaksanakan mulai dari tanggal 20 Januari 2021 melalui direct message Instagram. Pada penelitian ini menggunakan teknik pengumpulan data dengan cara observasi dan wawancara. Menurut Sarwono (2006) mengungkapkan bahwa observasi adalah kegiatan pencatatan secara sistematis mengenai suatu kejadian, perilaku, objek-objek yang dilihat dan hal-hal lainnya yang diperukan dalam mendukung penelitian yang dilaksanakan. Prastowo (2010) menjelaskan bahwa wawancara merupakan suatu metode pengumpulan data di mana adanya pertemuan antar dua orang atau lebih yang secara langsung untuk bertukar informasi ataupun ide dengan tanya jawab secara lisan sehingga dapat membangun makna dalam suatu topik tertentu. Peneliti melakukan wawancara terhadap 3 (tiga) informan yang diambil berdasarkan teknik pengumpulan data purposive sampling. Sugiyono (2020) mengungkapkan bahwa purposive sampling adalah teknik penentuan sampel dengan pertimbangan tertentu. Berikut ini beberapa kriteria yang ditentukan oleh peneliti dalam menentukan informan, di antaranya:

1. Informan merupakan seorang follower Instagram @ disarpus_kab.bandung 
2. Informan merupakan follower Instagram @disarpus_kab.bandung diambil secara random tanpa melihat perbedaan status, usia dan latar belakang pendidikan

3. Informan yang bersedia diwawancarai

Tabel 1.

Data informan

\begin{tabular}{|c|c|c|c|c|c|}
\hline No & Informan & $\begin{array}{c}\text { Jenis } \\
\text { Kelamin } \\
\end{array}$ & Status & Domisili & $\begin{array}{c}\text { Lama Mengikuti Instagram } \\
\text { @disarpus_kab.bandung }\end{array}$ \\
\hline 1 & $\begin{array}{c}\text { Ayu } \\
\text { Yauhana }\end{array}$ & Perempuan & Mahasiswi & Soreang & 2020 \\
\hline 2 & $\begin{array}{c}\text { Khaira } \\
\text { Amina Fitra }\end{array}$ & Perempuan & Pelajar & Cileunyi & 2018 \\
\hline 3 & Ismail & Laki-Laki & Mahasiswa & Soreang & 2019 \\
\hline
\end{tabular}

Sumber: Informan

\section{Hasil dan Pembahasan}

Penelitian Terdahulu

Penelitian yang dilakukan oleh Budiman, Ernita, dan Elfa (2019) yang berjudul Pemanfaatan Media Sosial Sebagai Sarana Promosi PERPUSDA Kabupaten Belitung Timur. Permasalahan pada penelitian ini ialah kurangnya minat baca dan minat kunjung masyarakat kabupaten Belitung Timur. Pentingnya promosi untuk memberitahukan kepada masyarakat terkait layanan-layanan dan keunggulan yang ada di perpustakaan PERPUSDA Kabupaten Belitung sangat dibutuhkan untuk menarik masyarakat berkunjung ke perpustakaan. Promosi yang dilakukan oleh PERPUSDA Kabupaten Belitung Timur yakni dengan memanfaatkan media sosial sebagai media promosinya. Pada penelitian ini menggunakan metode penelitian kualitatif pendekatan deskriptif. Hasil dari penelitian ini mengungkapkan bahwasanya dalam memanfaatkan media sosial sebagai media promosi berguna untuk memberitahukan sarana dan prasarana yang tersedia pada perpustakaan umum daerah Kabupaten Belitung Timur. Pemanfaatan media sosial ini juga berguna dalam promosi perpustakaan di mana pada kesehariannya mayoritas masyarakat mengakses media sosial. Dengan demikian promosi yang dilakukan dapat meningkatkan minat kunjung pemustaka untuk ke perpustakaan. Sehingga masyarakat dapat mengakses fasilitas yang tersedia di perpustakaan secara efektif dan efisien.

Penelitian yang dilakukan oleh Nuning Kurniasih (2016) yang berjudul Optimalisasi Penggunaan Media Sosial untuk Perpustakaan. Tujuan dari penelitian ini ialah untuk mendeskripsikan mengenai trend penggunaan media sosial di perpustakaan serta optimalisasi penggunaan media sosial di perpustakaan. Penelitian ini menggunakan metode penelitian kajian pustaka. Berdasarkan hasil dari penelitian ini dijelaskan bahwasanya pengelolaan media sosial oleh perpustakaan harus terencana dengan baik. Di mana perpustakaan harus dapat memahami jenis dan karakteristik dari media sosial yang akan digunakan. Dengan memahami jenis dan karakteristik media sosial tersebut perpustakaan dapat mengidentifikasi jenis konten yang dapat dibagikan sesuai dengan platform media sosial yang dipilih. Dalam pemilihan media sosial, ada baiknya perpustakaan harus mengetahui kebutuhan perpustakaan dan menganalisis jenis media sosial yang banyak digunakan oleh target pemustakanya. Melalui media sosial juga dapat memberi konsekuensi pada perpustakaan di mana perpustakaan dapat lebih cepat memberikan pelayanan. Melalui pemanfaatan media sosial diharapkan perpustakaan dapat membangun kedekatan dengan masyarakan dan memberikan pelayanan terbaiknya.

Penelitian yang dilakukan oleh Putu, dkk (2018) dengan judul Evaluasi Kegiatan Promosi Perpustakaan Umum (Studi Kasus pada Dinas Perpustakaan dan Kearsipan Kota Denpasar). Tujuan dari penelitian ini ialah untuk mengetahui kegiatan promosi Dinas Perpustakaan dan Kearsipan Kota 
Denpasar. Metode penelitian yang digunakan pada penelitian ini ialah metode kualitatif deskriptif. Hasil dari penelitian ini mengungkapkan bahwa promosi Dinas Perpustakaan dan Kearsipan Kota Denpasar menggunakan media promosi pamflet, website, media periklanan, bimbingan teknis, perpustakaan keliling, dan pameran. Selain itu diketahui bahwasanya media promosi yang paling efektif digunakan ialah perpustakaan keliling dan penyelenggaraan pameran. Selain itu dalam kegiatan promosi yang dilakukan oleh Dinas Perpustakaan dan Kearsipan Kota Denpasar memiliki beberapa kendala baik dalam faktor internal dan eksternal. Kendala yang dihadapi dalam promosi pada faktor internal berupa anggaran dalam menunjang kegiatan promosi, diskusi dan evaluasi kegiatan promosi. Sedangkan faktor eksternal yang menjadi kendalanya ialah kurangnya minat kunjung masyarakat untuk datang ke pameran yang diselenggarakan oleh Dinas Perpustakaan dan Kearsipan Kota Denpasar.

\section{Elemen AIDA (Attention, Interest, Desire, Action)}

Dalam kegiatan promosi membutuhkan sebuah konsep yang dapat membantu perpustakaan dalam mencapai tujuan yang diharapkan, salah satunya dengan menggunakan elemen AIDA (Attention, Interest, Desire, Action). Qalyubi (2003) mengungkapkan bahwa terdapat beberapa unsur tingkatan dalam pengenalan produk kepada khalayak seperti Attention atau perhatian, Interest atau ketertarikan, Desire atau keinginan, dan Action atau Tindakan. Kotler dan Keller (2015) mengungkapkan bahwa teori AIDA merupakan satu pesan yang harus mendapatkan perhatian, menjadi ketertarikan minat dan mengambil tindakan. Konsep AIDA ini sebagai alat promosi yang dapat menarik perhatian, mendorong minat, membangkitkan keinginan dan menghasilkan tindakan. Menurut Keller (2007) AIDA terdiri dari

1. Attention (Perhatian)

Dalam mempromosikan produk atau jasa, iklan harus menarik perhatian khalayak sasarannya, baik pembaca, pendengar atau pemirsa.

2. Interest (Minat)

Setelah perhatian dari sasaran, selanjutnya penyedia jasa atau produk harus memikirkan bagaimana caranya agar sasaran dapat lebih berminat dan merasa ingin tahu lebih jauh terkait promosi yang menarik perhatian. Untuk itu, sasaran perlu di rangsang agar lebih berminat dan mengikuti pesan-pesan yang disampaikan dengan menggunakan kata-kata yang bersifat mengajak orang untuk tahu lebih lanjut.

3. Desire (Keinginan)

Apabila sasaran telah memiliki minat untuk menginginkan produk atau jasa yang dipromosikan, maka promosi tersebut berhasil untuk menarik sasaran agar menggunakan produk dan jasa tersebut. Keinginan sasaran untuk memiliki, memakai, menikmati atau melakukan sesuatu harus dibangkitkan dengan kalimat-kalimat tertentu.

4. Action (Tindakan)

Pada poin ini, penyedia jasa atau produk harus dapat membujuk konsumen agar sesegera mungkin untuk memutuskan tindakan penggunaan produk atau jasa yang dipromosikan. Dalam hal ini perlunya pemilihan kata perintah yang tepat agar pada promosi dilihat dan didengarkan oleh sasaran. Dengan demikian sasaran tidak akan ragu dalam mengambil keputusan untuk menggunakan produk atau jasa yang ditawarkan.

\section{Media Sosial Instagram}

Media sosial merupakan media untuk berinteraksi sosial antara pengguna satu dengan pengguna lainnya. Menurut Van Dijk (2013) mengungkapkan bahwa media sosial merupakan sebuah platform yang berfokuskan pada eksistensi penggunanya serta memfasilitasi pengguna dalam melakukan interaksi dengan pengguna lain. Media sosial dijadikan media online yang dapat 
menguatkan hubungan pengguna dalam sebuah ikatan sosial berbasis online. Rulli Nasrullah (2017) mengungkapkan bahwa media sosial memiliki beberapa karakteristik, di antaranya

1. Jaringan (Network)

Media sosial memiliki karakteristik membentuk jaringan serta sebagai perantara bagi pengguna tanpa memandang kedekatan antar pengguna dalam kehidupan nyata. Keberadaan media sosial mewadahi pengguna untuk terhubung secara mekanisme teknologi. Jaringan yang terbentuk antarpengguna ini menjadikan membentuk komunitas atau masyarakat yang secara sadar atau tidak memunculkan nilai-nilai yang ada di masyarakat sebagaimana dalam ciri masyarakat pada teori-teori sosial.

2. Informasi (Information)

Informasi merupakan kebutuhan utama dalam media sosial di mana informasi di produksi, didistribusikan antar pengguna. Industri media sosial seperti perusahaan Facebook, Twitter, ataupun Instagram juga menjadikan informasi sebagai sumber daya. Rulli Nasrullah (2017) mengungkapkan bahwa berdasarkan sisi institusi, media sosial dapat dibangun berdasarkan informasi yang dikodekan (encoding) yang selanjutnya didistribusikan dengan berbagai perangkat sehingga dapat diakses oleh pengguna (decoding). Rulli Nasrullah (2017) juga mengungkapkan bahwa penggunaan media sosial dari segi sisi pengguna informasi dijadikan landasan untuk dapat berinteraksi dan membentuk masyarakat yang berjejaring.

3. Arsip (Archive)

Segala informasi yang terdapat pada media sosial dapat disimpan dan diakses kapanpun. Informasi yang telah diunggah pada media sosial akan tetap tersimpan tanpa ada batasan waktu. Sebagai contohnya adalah unggahan video atau foto, unggahan yang disukai, hingga siapa saja pengguna yang membentuk jaringan pertemanan akan tersimpan dalam media sosial tanpa ada batasan waktu.

4. Interaksi (Interactivity)

Secara sederhananya interaksi yang terjadi pada media sosial minimal dengan mengomentari atau menyukai unggahan pengguna lain. Interaksi dalam sebuah kajian media menjadi pembeda antara media lama (old media) dengan media baru (new media). Holmes (2005) mengungkapkan bahwa dalam media lama pengguna atau khalayak media merupakan khalayak pasif dan cenderung tidak bisa berinteraksi baik antar pengguna lain ataupun dengan produser konten media.

Instagram merupakan salah satu media sosial yang hingga saat ini banyak digunakan oleh masyarakat dunia, termasuk di Indonesia. Instagram merupakan media sosial yang dapat dimanfaatkan sebagai media pemasaran secara langsung. Di mana Instagram memfasilitasi penggunanya untuk mengunggah foto dan video. Nisrina (2015) mengungkapkan bahwa Instagram sebagai aplikasi yang digunakan untuk membagi foto membuat banyak pengguna terjun ke bisnis online turut mempromosikan produk-produknya lewat Instagram dengan semakin populernya media sosial Instagram di kalangan masyarakat. Dengan demikian Instagram juga dapat dijadikan media promosi bagi perpustakaan. Tersedianya fitur-fitur yang mendung dalam aplikasi Instagram semakin memudahkan seseorang dalam mempromosikan produk/jasa. Menurut Novita Sari (2018) terdapat beberapa fitur dalam Instagram, di antaranya

1. Pengikut

Pada sistem sosial dalam aplikasi Instagram ialah dengan menjadi pengikut (following) akun pengguna lain atau dengan memiliki pengikut (follower) pada akun Instagram yang kita miliki. Dengan demikian pengguna dapat berinteraksi dengan memberikan tanda suka (like), mengomentari foto ataupun video yang diunggah dan dapat berkomunikasi melalui pesan personal via direct message. Jumlah pengikut dan jumlah tanda suka (like) yang didapat dapat berpengaruh terhadap kepopuleran suatu akun Instagram tersebut. 
2. Mengunggah Foto dan Video

Instagram merupakan salah satu media sosial yang memfasilitasi penggunanya untuk mengunggah foto dan video. Foto dan video yang diunggah dapat diperoleh dari kamera perangkat yang digunakan. Dalam Instagram juga terdapat fitur select multiple di mana pengguna dapat mengunggah video dan foto paling banyak 10 foto dan video dalam satu kali unggahan.

3. Kamera dan Efek Foto (Filter)

Penggunaan kamera pada aplikasi Instagram dapat langsung menggunakan efek-efek foto yang sudah tersedia. Hasil foto pada kamera Instagram bisa tersimpan di perangkat yang digunakan oleh pengguna. Adanya efek foto (filter) berfungsi untuk mempertajam warna foto sebelum diunggah agar tampak lebih menarik.

4. Judul Foto (Caption)

Caption atau judul foto berfungsi sebagai pemberi keterangan pada foto yang telah disunting dan siap untuk diunggah ke dalam Instagram. Selain itu dalam caption juga dapat mencantumkan lokasi dan menandai pengguna lain dengan mencantumkan nama akun penggunanya.

5. Arroba

Instagram dapat menandai (tag) pengguna lain dengan menambahkan tanda arroba (@) dan memasukkan nama akun Instagram dari pengguna tersebut. Penggunaan arroba ini dapat digunakan dalam caption foto yang diunggah maupun pada kolom komentar.

6. Jejaring Sosial

Dalam membagikan foto, para pengguna Instagram dapat membagikannya ke media sosial lainnya seperti Facebook, dan Twitter yang tersedia pada halaman Instagram.

7. Tanda suka (Like)

Instagram memiliki tanda suka di mana pengguna lain dapat menyukai foto atau video yang telah diunggah.

8. Populer (explore)

Populer atau explore merupakan salah satu fitur yang ada dalam Instagram di mana pengguna dapat melihat foto pengguna lain. Foto yang masuk ke dalam halaman explore merupakan foto yang dikenali banyak orang atau yang memiliki jumlah like terbanyak.

9. Insta Stories

Pada fitur ini memungkinkan pengguna mengirim foto dan video yang dapat menggunakan filter-filter menarik. Pada insta stories juga terdapat pilihan untuk merekam video secara online atau live streaming, boomerang, handsfree dan lainnya. Foto ataupun video yang diunggah dalam insta stories hanya berlaku dalam 1 × 24 jam.

\section{Promosi Perpustakaan}

Pada dasarnya promosi tak lepas dari pemasaran. Kotler (2006) mengungkapkan bahwa dalam pemasaran sering menggunakan istilah 4P yang berpengaruh terhadap tanggapan konsumen mengenai produk atau jasa yang ditawarkan oleh suatu organisasi atau perusahaan. 4P terdiri dari

1. Produk (Product)

Produk atau jasa yang ada di perpustakaan biasanya berupa koleksi perpustakaan, jasa layanan yang ada dan lain sebagainya.

2. Harga (Price)

Perpustakaan merupakan salah satu organisasi nirlaba yang tidak menetapkan harga untuk produk atau jasa yang diberikan. Namun ada juga beberapa perpustakaan yang mengambil keuntungan dari pelayanan yang diberikan. Contohnya seperti denda telat pengembalian buku. 
3. Distribusi atau Tempat (Place)

Dalam perpustakaan, unsur distribusi atau tempat ini berhubungan dengan penyebaran produk atau jasa informasi kepada pengguna perpustakaan.

Menurut Buchari Alma (2002) mengungkapkan bahwa promosi merupakan salah satu jenis komunikasi berupa penjelasan untuk meyakinkan orang agar produk atau jasa yang ditawarkan mendapat perhatian konsumen. Selaras dengan pendapat tersebut, Mustafa (2010) juga mendefinisikan bahwa promosi adalah usaha untuk memajukan dan meningkatkan popularitas produk atau jasa yang akan dipasarkan. Menurut Lasa (2009) menjelaskan bahwa promosi merupakan pertukaran informasi antar organisasi/lembaga dan konsumen dengan tujuan utama untuk memberi informasi mengenai produk atau jasa yang tersedia dalam organisasi dan membujuk calon konsumen untuk berinteraksi pada produk atau jasa tersebut. Berdasarkan pendapat para ahli di atas, diketahui bahwasanya promosi merupakan kegiatan komunikasi yang dilakukan untuk menjelaskan dan meyakinkan orang terhadap produk dan jasa yang akan dipasarkan guna untuk meningkatkan popularitas produk ataupun jasa tersebut.

Promosi perpustakaan merupakan salah satu upaya yang dilakukan oleh perpustakaan untuk tertarik agar datang ke perpustakaan. Sutarno NS (2008) mengungkapkan bahwa promosi perpustakaan adalah suatu kegiatan masyrakat dan mensosialisasikan perpustakaan melalui media cetak langsung/tidak langsung tatap muka agar orang tahu dan tertarik ke perpustakaan. Selain itu, Umami (2018) juga mengungkapkan bahwa promosi perpustakaan merupakan rangkaian kegiatan perpustakaan yang dirancang agar pemustaka mengetahui manfaat sebuah perpustakaan melalui layanan yang disediakan oleh sebuah perpustakaan. Berdasarkan beberapa pendapat di atas, dapat ditarik kesimpulan bahwasanya promosi perpustakaan merupakan salah satu kegiatan perpustakaan untuk mengenalkan keberadaan dan fungsi perpustakaan kepada khalayak dan menarik minat kunjung khalayak untuk datang ke perpustakaan.

\section{Perpustakaan Umum}

Menurut IFLA (International Federation of Library Associations and Institutions) mengungkapkan bahwa perpustakaan umum merupakan perpustakaan yang didirikan dan dibiayai oleh pemerintah daerah atau pemerintah pusat. Rosenfeldt (2006) menjelaskan bahwa perpustakaan umum merupakan pintu gerbang pengetahuan dan tempat bagi masyarakat untuk mengekspresikan kreativitas, tempat hiburan dan akses gratis ke layanan informasi). Berdasarkan pendapat para ahli di atas, dapat diketahui bahwasanya perpustakaan umum merupakan perpustakaan yang didirikan oleh pemerintah untuk masyarakat umum yang menyediakan beragam informasi yang dibutuhkan dengan akses gratis.

Sutoyo (2001) mengungkapkan bahwa tujuan dari didirikannya perpustakaan umum ialah

1. Mengembangkan minat budaya tulisan dalam segala sektor kehidupan pada umumnya.

2. Mengembangkan kemampuan mencari, mengolah dan memanfaatkan informasi.

3. Mendidik masyarakat dalam memelihara dan memanfaatkan bahan pustaka dengan tepat.

4. Meletakkan dasar-dasar ke arah belajar mandiri

Pada dasarnya perpustakaan umum memiliki peranan dalam mencerdaskan kehidupan bangsa.

Menurut Sutarno (2003) perpustakaan umum memiliki beberapa peranan, di antaranya:

1. Perpustakaan merupakan fasilitator penghubung antara penyedia sumber informasi dan pengguna perpustakaan

2. Perpustakaan memiliki peranan aktif sebagai sarana untuk menjalin dan mengembangkan komunikasi antar pengguna dan penyelenggara perpustakaan

3. Perpustakaan bisa berperan sebagai lembaga yang dapat mengembangkan minat baca melalui penyediaan bahan bacaan yang sesuai dengan keinginan dan kebutuhan penggunanya 
4. Perpustakaan dapat berperan aktif sebagai penyedia fasilitas, media dan motivator bagi pengguna yang hendak mencari, memanfaatkan dan mengembangkan ilmu pengetahuannya melalui koleksi perpustakaan yang ada

5. Perpustakaan berpartisipasi dalam agen perubahan, pengembangan dan pembangunan kebudayaan manusia

6. Perpustakaan memiliki peranan sebagai lembaga pendidikan nonformal bagi pengguna perpustakaan.

Dinas Arsip dan Perpustakaan Kabupaten Bandung merupakan perpustakaan daerah Kabupaten Bandung yang memanfaatkan media sosial Instagram sebagai media promosi. Dinas Arsip dan Kabupaten Bandung memiliki akun resmi @disarpus_kab.bandung sejak tahun 2017. Sampai saat ini, jumlah pengikut (follower) dari akun@disarpus_kab.bandung mencapai 1.246 pengikut dan terdapat mengikuti akun pengguna lain sebanyak 237 mengikuti (following). Sebagaimana yang telah dipaparkan di atas, penelitian ini bertujuan untuk mengetahui kegiatan promosi yang dilakukan oleh Dinas Arsip dan Perpustakaan Kabupaten Bandung melalui akun Instagram @disarpus_ka.bandung yang di analisis menggunakan Elemen AIDA. Berikut ini merupakan hasil observasi dan wawancara yang penulis lakukan terhadap pengikut akun Instagram @ disarpus_kab.bandung, di antaranya

1. Attention (Perhatian)

Pada kegiatan promosi, elemen perhatian (attention) ini merupakan elemen pembuka ketika hendak melaksanakan kegiatan promosi sebuah produk atau jasa. Di mana dalam elemen ini penyedia jasa atau produk mengambil simpatik khalayak agar mau menggunakan produk/jasa yang dipromosikan. Dalam upaya promosi perpustakaan, Dinas Arsip dan Perpustakaan Kabupaten Bandung mengunggah konten berupa foto dan video kegiatan perpustakaan dalam laman akun Instagram @ disarpus_kab.bandung secara menarik dengan menggunakan layout dan desain grafis. Berdasarkan hasil wawancara 2 dari 3 informan, yakni Ayu dan Ismail, berpendapat jika promosi yang dilakukan oleh Dinas Arsip dan Perpustakaan Kabupaten Bandung@disarpus_kab.bandung kurang maksimal. Informan berpendapat bahwa konten yang dimuat dalam akun Instagram @disarpus_kab.bandung kurang menarik dan cenderung monoton. Selain itu, informan mengungkapkan bahwa perlunya penataan layout dan desain dalam pengunggahan foto dan video agar lebih menarik. Sedangkan 1 dari 3 informan, yakni Khaira, mengungkapkan bahwa promosi yang dilakukan oleh Dinas Arsip dan Perpustakaan Kabupaten Bandung dalam akun Instagram @disarpus_kab.bandung dirasa menarik dengan desain dan layout unggahan. Miranda (2015) mengungkapkan bahwa dalam upaya mempromosikan produk atau jasa seorang pemasar harus dapat membuat suatu pernyataan yang mengungkapkan perhatian orang, membuat kata atau gambar yang bisa menarik perhatian hingga orang berhenti dan memperhatikan isi pesan berikutnya.

2. Interest (Minat)

Assael (2002) mengungkapkan bahwa dalam elemen interest ditandai dengan munculnya minat khalayak terhadap produk/jasa yang dikenalkan oleh suatu pemasar. Untuk menarik minat pengguna agar dapat memanfaatkan perpustakaan, Dinas Arsip dan Kabupaten Bandung berupaya memberikan infomasi dengan mengunggah foto dan video yang dilengkapi dengan caption/judul foto di setiap unggahannya. Caption/judul foto unggahan ditulis sedemikian rupa menggunakan kata-kata dan kalimat-kalimat persuatif agar pemustaka dapat menarik minat pengguna untuk mencari tahu lebih dalam mengenai informasi tentang Dinas Arsip dan Perpustakaan Kabupaten Bandung. Berdasarkan hasil wawancara dengan informan, 2 dari 3 informan, yakni Ayu dan Khaira, mengungkapkan adanya caption pada setiap unggahan foto dan video di akun Instagram @disarpus_kab.bandung dirasa cukup informatif dan jelas serta pemilihan kata yang tepat. Dengan adanya caption yang informatif 
dan jelas dapat menumbuhkan minat untuk mencari tahu tentang Dinas Arsip dan Perpustakaan Kabupaten Bandung. Ismail mengungkapkan unggahan foto dan video dalam akun Instagram @disarpus_kab.bandung kurang menarik minatnya untuk mengetahui mengenai Dinas Arsip dan Perpustakaan Kabupaten Bandung. Sedangkan 1 dari 3 informan, yakni Ismail, mengungkapkan bahwa informasi melalui caption yang dicantumkan dalam akun Instagram @disarpus_kab.bandung pemilihan katanya kurang tepat dan cenderung kaku sedangkan mayoritas pengikutnya merupakan generasi milenial.

3. Desire (Keinginan)

Elemen Desire (keinginan) merupakan elemen yang berkaitan dengan sikap khalayak terhadap suatu produk/jasa yang disukainya. Berdasarkan hasil wawancara 2 dari 3 informan, yakni Ayu dan Khaira, mengungkapkan bahwa elemen keinginan (desire) telah berhasil menggerakkan keinginan informan melalui promosi yang disampaikan pada unggahan foto ataupun video dalam akun Instagram @disarpus_kab.bandung. Di mana kedua informan tersebut memiliki keinginan untuk mencari tahu lebih mengenai kegiatan yang ada di Dinas Arsip dan Perpustakaan Kabupaten Bandung dengan mengunjungi Instagram Dinas Arsip dan Perpustakaan Kabupaten Bandung. Sedangkan 1 dari 3 informan, yakni Ismail, mengungkapkan bahwa unggahan foto dan video Dinas Arsip dan Kabupaten Bandung dalam akun@disarpus_kab.bandung kurang membangkitkan keinginan informan untuk mengetahui informasi lebih lanjut terkait Dinas Arsip dan Perpustakaan Kabupaten Bandung. Kusumadewi (2015) mengungkapkan bahwasanya dalam menumbuhkan keinginan (desire) pada konsumen, pemasar harus memastikan bahwa khalayak memperoleh berbagai informasi produk atau jasa yang ditawarkan.

4. Action (Tindakan)

Elemen tindakan merupakan elemen akhir dari proses sebuah promosi di mana pada elemen ini khalayak mulai memutuskan untuk menggunakan produk/jasa yang dipromosikan. Berdasarkan hasil wawancara, 2 dari 3 informan, yakni Ayu dan Khaira, mengungkapkan bahwa promosi yang dilakukan oleh Dinas Arsip dan Perpustakaan Kabupaten Bandung dalam akun Instagram @disarpus_kab.bandung telah berhasil membuat informan untuk memanfaatkan fasilitas Dinas Arsip dan Perpustakaan Kabupaten Bandung. Melalui unggahan foto dan video membuat informan memiliki keputusan untuk berkunjung dan memanfaatkan fasilitas yang ada di Dinas Arsip dan Perpustakaan Kabupaten Bandung. Sedangkan 1 dari 3 informan, yakni Ismail, mengungkapkan bahwa promosi yang dilakukan Dinas Arsip dan Perpustakaan Kabupaten Bandung dalam Instagram @ disarpus_kab.bandung kurang untuk mengambil keputusan agar informan berkunjung dan memanfaatkan fasilitas di Dinas Arsip dan Perpustakaan Kabupaten Bandung. Informan mengungkapkan bahwa keputusannya untuk mengunjungi dan memanfaatkan fasilitas didasari karena kebutuhan bukan berdasarkan promosi yang ada pada akun Instagram @disarpus_kab.bandung. Kusumadewi (2015) mengungkapkan bahwa kesesuaian produk atau jasa yang ditawarkan calon konsumen percaya bahwa produk atau jasa yang dipilih sesuai dengan apa yang ditawarkan.

\section{Kesimpulan}

Berdasarkan hasil penelitian di atas, dapat disimpulkan bahwasanya upaya promosi yang dilakukan Dinas Arsip dan Perpustakaan Kabupaten Bandung melalui media sosial Instagram @disarpus_kab.bandung dapat dikatakan kurang memenuhi elemen AIDA yakni attention. Di mana kurangnya pemilihan konten layout dan desain grafis dalam unggahan yang terdapat pada akun Instagram @disarpus_kab.bandung. Dengan demikian, dalam upaya promosi yang dilakukan Dinas Arsip dan Perpustakaan Kabupaten Bandung dalam akun Instagram @disarpus_kab.bandung 
diharapkan dapat memperhatikan konten layout dan desain grafis yang akan diunggah dalam akun Instagram-nya. Dengan memperhatikan konten layout dan desain grafis tentunya memiliki nilai tambah bagi akun@disarpus_kab.bandung untuk menarik masyarakat Kabupaten Bandung mengikuti akun Instagram @disarpus_kab.bandung.

\section{Daftar Pustaka}

Amara Derlika \& Saepudin E (2019). Kegiatan promosi perpustakaan melalui Instagram kaitannya dengan perubahan sikap followers Jurnal Pustaka Budaya, 6(2): 12-21. [Accessed 14 Januari 2021]. DOI: $10.31849 /$ pb.v6i2.3183

Budiman EA \& Ronaning E (2019) Pemanfaatan media sosial sebagai sarana promosi PERPUSDA Kabupaten Belitung Timur Jurnal Ranah Komunikasi, 3(1): 34-44. [Accessed 14 Januari 2021]. https://doi.org/10.25077/rk.3.1.34-44.2019

Iryanti YS \& Rahman MA (2019) Promosi perpustakaan melalui media sosial twitter di perpustakaan Hukum Daniel S. Lev. EDULIB, 9(2): 128-143.[Accessed 15 Januari 2021]. https://doi.org/10.17509/edulib.v9i2.17763.g10595.

Karminah W (2016) Bauran promosi jasa perpustakaan (Studi evaluasi model CIPP pada bauran promosi di UPT perpustakaan ISI Surakarta tahun 2010-2014 Jurnal Khizanah Al-Hikmah, 4(1): 91-103. DOI: 10.24252/kah.v4i1a8.

Nasrullah R. (2017) Media sosial: Perspektif, budaya dan sosio teknologi Bandung: Simbiosa Rekatama Media.

Pratiwi KF (2018) Analisis elemen AIDCA di Balai Layanan Perpustakaan BPAD DIY (Studi deskriptif analisis elemen AIDCA pada Instagram, twitter dan facebook sebagai promosi di Balai Layanan Perpustakaan BPAD DIY) 1-13. [Accessed 16 Januari 2021]. http://repository.unair.ac.id/id/eprint/75030

Prastowo A (2016) Metode Penelitian Kualitatif Dalam Perspektif Rancangan Penelitian. Yogyakarta: Ar-Ruzz Media.

Ahmadi R (2016) Metodologi Penelitian Kualitatif Yogyakarta: Ar-Ruzz Media. 